\title{
STRATEGI PENCEGAHAN ENDEMI HIV/AIDS DENGAN MENGGUNAKAN PEMODELAN MATEMATIKA
}

\author{
Ismanto $^{1}$, M. Ivan Ariful Fathoni ${ }^{2}$ \\ Universitas Nahdlatul Ulama Sunan Giri, Jl. A.Yani No.10, Bojonegoro \\ ${ }^{1}$ ismanto0901@ unugiri.ac.id
}

\begin{abstract}
Abstrak
HIV merupakan virus yang dapat menyebabkan rusaknya sistem kekebalan tubuh. WHO memperkirakan AIDS telah membunuh lebih dari 25 juta orang sejak pertama kali diakui pada tanggal 5 Juni 1981. Indonesia masih memiliki angka penderita HIV yang relatif tinggi. Penderita HIV di Indonesia tidak lagi di kota-kota besar, namun juga penduduk di kota-kota kecil. Bojonegoro merupakan kota kecil yang ada di Provinsi Jawa Timur dengan jumlah penduduk sekitar 1.408.089 jiwa manusia. Pada saat ini Bojonegoro menjadi salah satu pusat tambang minyak di Indonesia. Meningkatnya proyek migas di Blok-Cepu serta pesatnya pembangunan menimbulkan dampak sosial yang negatif di tengah masyarakat. Terutama banyaknya tempat-tempat prostitusi yang memicu penularan penyakit HIV/AIDS di Bojonegoro. Jumlah kasus HIV/AIDS di Kabupaten Bojonegoro semakin meningkat dari tahun ke tahun. Hal ini perlu mendapatkan perhatian yang serius. Model matematika seringkali digunakan untuk menjelaskan fenomena dalam bidang biologi, seperti model penyebaran penyakit menular. Fenomena tersebut dimodelkan oleh persamaan diferensial dengan representasi proses waktu kontinu. Populasi penduduk Bojonegoro yang sehat, terinfeksi HIV, dan pengidap AIDS, serta populasi serupa di kota lain yang warganya melakukan perpindahan penduduk ke bojonegoro dimodelkan dalam bentuk sistem persamaan diferensial. Analisis terhadap sistem diperoleh titik kesetimbangan bebas penyakit dan titik kesetimbangan endemik. Bilangan reproduksi dasar $\left(R_{0}\right)$ menentukan kestabilan dari titik kesetimbangan dan parameter-parameter yang dapat dikendalikan dalam upaya pencegahan endemi HIV/AIDS di Kab.Bojonegoro. Hasil pembahasan menunjukkan jika Kab.Bojonegoro dalam kondisi endemi HIV/AIDS dibuktikan dengan nilai $R_{0}>1$. Strategi pencegahan endemi dapat dilakukan dengan menurunkan rate penularan dan rate perpindahan penduduk sampai diperoleh $R_{0}<1$. Dengan nilai $R_{0}<1$, maka akan diperoleh kondisi Kab.Bojonegoro yang bebas penyakit.
\end{abstract}

Kata Kunci: HIV/AIDS, Model Matematika, Sistem Dinamik, Persamaan Diferensial

\begin{abstract}
HIV is a virus that can cause damage to the immune system. WHO estimates that AIDS has killed more than 25 million people since it was first recognized on June 5, 1981. Indonesia still has a relatively high number of people with HIV. HIV sufferers in Indonesia are no longer in big cities, but also residents in small cities. Bojonegoro is a small city in East Java Province with a population of around 1,408,089 people. At present, Bojonegoro is one of the centers of oil mining in Indonesia. The increase in oil and gas projects in Blok-Cepu and the rapid development have caused negative social impacts in the community. Especially the number of places of prostitution that trigger transmission of HIV / AIDS in Bojonegoro. The number of HIV / AIDS cases in Bojonegoro Regency is increasing year by year. This needs serious attention. Mathematical models are often used to explain phenomena in the field of biology, such as the model of the spread of infectious diseases. This phenomenon is modeled by differential equations with representations of continuous time processes. A healthy population of Bojonegoro, infected with HIV, and people with AIDS, as well as a similar population in another city whose residents migrated to Bojonegoro, was modeled in the form of a system of differential equations. Analysis of the system obtained disease-free equilibrium points and endemic equilibrium points. Basic reproductive numbers $\left(R_{0}\right)$ determine the stability of the
\end{abstract}


equilibrium point and the parameters that can be controlled in an effort to prevent the endemic HIV / AIDS in Bojonegoro District. The results of the discussion show that if Bojonegoro Regency is in an HIV / AIDS endemic condition, it is proven by the value of $R_{0}<1$. An endemic prevention strategy can be carried out by reducing the transmission rate and population transfer rate to obtain $R_{0}<1$. With a value of $R_{0}<1$, the condition of Bojonegoro Regency which is disease free will be obtained.

Keywords: HIV/AIDS, Mathematical Models, Dynamic Systems, Differential Equations

\section{Pendahuluan}

HIV (Human Immunodeficiency Virus) merupakan virus yang dapat menyebabkan AIDS (Acquired Immune Deficiency Syndrome) dengan cara menyerang sel darah putih yang bernama sel CD4+ sehingga mengakibatkan rusaknya sistem kekebalan tubuh. HIV dapat ditularkan melalui kontak langsung dengan darah atau cairan tubuh seseorang yang terinfeksi virus. Penggunaan jarum suntik secara bergantian atau melakukan hubungan seks yang tidak terlindungi dengan orang yang terinfeksi juga dapat menjadi resiko HIV, termasuk seorang bayi bisa tertular HIV dari ibu yang terinfeksi. Ketika tubuh manusia terkena HIV, maka sesorang tidak langsung mengidap AIDS, melainkan diperlukan waktu yang cukup lama bahkan bertahuntahun bagi HIV untuk menyebabkan AIDS. Hingga saat ini, belum ada obat yang dapat menyembuhkan AIDS.

WHO (World Health Organization) menyatakan bahwa AIDS telah membunuh lebih dari 25 juta orang sejak pertama kali diakui pada tanggal 5 Juni 1981. Pada tahun 2005 saja, AIDS diklaim telah menyebabkan kematian sebanyak 2,4 hingga 3,3 juta jiwa, lebih dari 570.000 jiwa diantaranya adalah anak-anak. Di Indonesia, HIV/AIDS pertama kali ditemukan di Provinsi Bali pada tahun 1987. Hingga saat ini HIV/AIDS sudah menyebar di 407 dari 507 kabupaten/kota (80\%) di seluruh provinsi di Indonesia. Penderita HIV adalah penderita yang menurut hasil pemeriksaan laboratorium dinyatakan positif HIV. Jumlah kumulatif penderita HIV di Indonesia sampai Juni 2016 sebanyak 208.920 orang, sedangkan total kumulatif kasus AIDS sebanyak 82.556 orang. Berdasarkan laporan provinsi, jumlah (kumulatif) kasus infeksi HIV yang terbanyak adalah Provinsi DKI Jakarta (41.891 kasus), kemudian disusul oleh Provinsi Jawa Timur (27.575 kasus) (Infodatin, 2016).

Penderita HIV di Indonesia sudah merata. Bojonegoro merupakan kota kecil yang ada di Provinsi Jawa Timur dengan jumlah penduduk sekitar 1.408.089 jiwa manusia. Meningkatnya proyek migas di Blok-Cepu di Bojonegoro serta menimbulkan dampak sosial yang negatif di tengah masyarakat. Terutama banyaknya tempat-tempat prostitusi yang memicu penularan penyakit HIV/AIDS di Bojonegoro. Dinas Kesehatan Bojonegoro menerangkan bahwa jumlah 
pengidap HIV di Bojonegoro dari tahun ke tahun semakin meningkat. HIV/AIDS yang ada di Bojonegoro sebagian dibawa oleh para pendatang, dan sebagian yang lain berasal dari penduduk asli. Hal ini perlu mendapatkan perhatian yang serius karena HIV/AIDS akan memberikan dampak yang sangat besar jika tidak ditanggulangi. Dampak yang ditimbulkan diantaranya adalah menurunnya tingkat kesejahteraan penduduk, karena penderita HIV tidak mampu bekerja secara optimal sedangkan sebagian besar penderita HIV/AIDS adalah kelompok usia produktif yang menjadi tumpuan perekonomian keluarga. Pengobatan HIV/AIDS juga memerlukan biaya yang relatif mahal. Untuk mencegah endemi HIV/AIDS di Bojonegoro, perlu adanya kerjasama dari berbagai lintas sektor, seperti pemerintah, masyarakat, praktisi, dan juga akademisi (Dinkes Kab.Bojonegoro, 2016).

Model matematika seringkali digunakan untuk menjelaskan fenomena dalam bidang biologi, seperti model penyebaran penyakit menular. Fenomena tersebut dimodelkan oleh persamaan diferensial dengan representasi proses waktu kontinu. Wan dan Cui (2007) meneliti tentang tingkahlaku dari epidemi ketika adanya imigrasi atau transportasi dari populasi antar dua wilayah. Jiang, dkk. (2010) membuat model epidemi SIR dengan dua kategori gangguan stokastik. Marsudi, dkk. (2013) melakukan penelitian analisa kestabilan penyebaran HIV/AIDS dengan edukasi kesehatan melalui perluasan model SI (susceptible-infected), dampak edukasi kesehatan pada penyebaran penyakit HIV/AIDS dikaji dengan analisis sensitivitas angka reproduksi efektif terhadap semua parameter yang mendorong dinamika penyakit. Eduafo, dkk. (2015) membahas tentang model SIA transmisi HIV di Ghana. Berdasarkan referensi dari penelitian yang telah dilakukan sebelumnya, dalam penelitian ini dikaji model matematika dinamika transmisi atau penularan HIV/AIDS yang ada di Kab.Bojonegoro.

\section{Metode Penelitian}

Untuk memperjelas kerangka konseptual penelitian, berikut ini adalah diagram alir penelitian strategi pencegahan endemi HIV/AIDS di Kabupaten Bojonegoro dengan menggunakan analisis sistem dinamik, yang ditunjukkan oleh Gambar 1. 


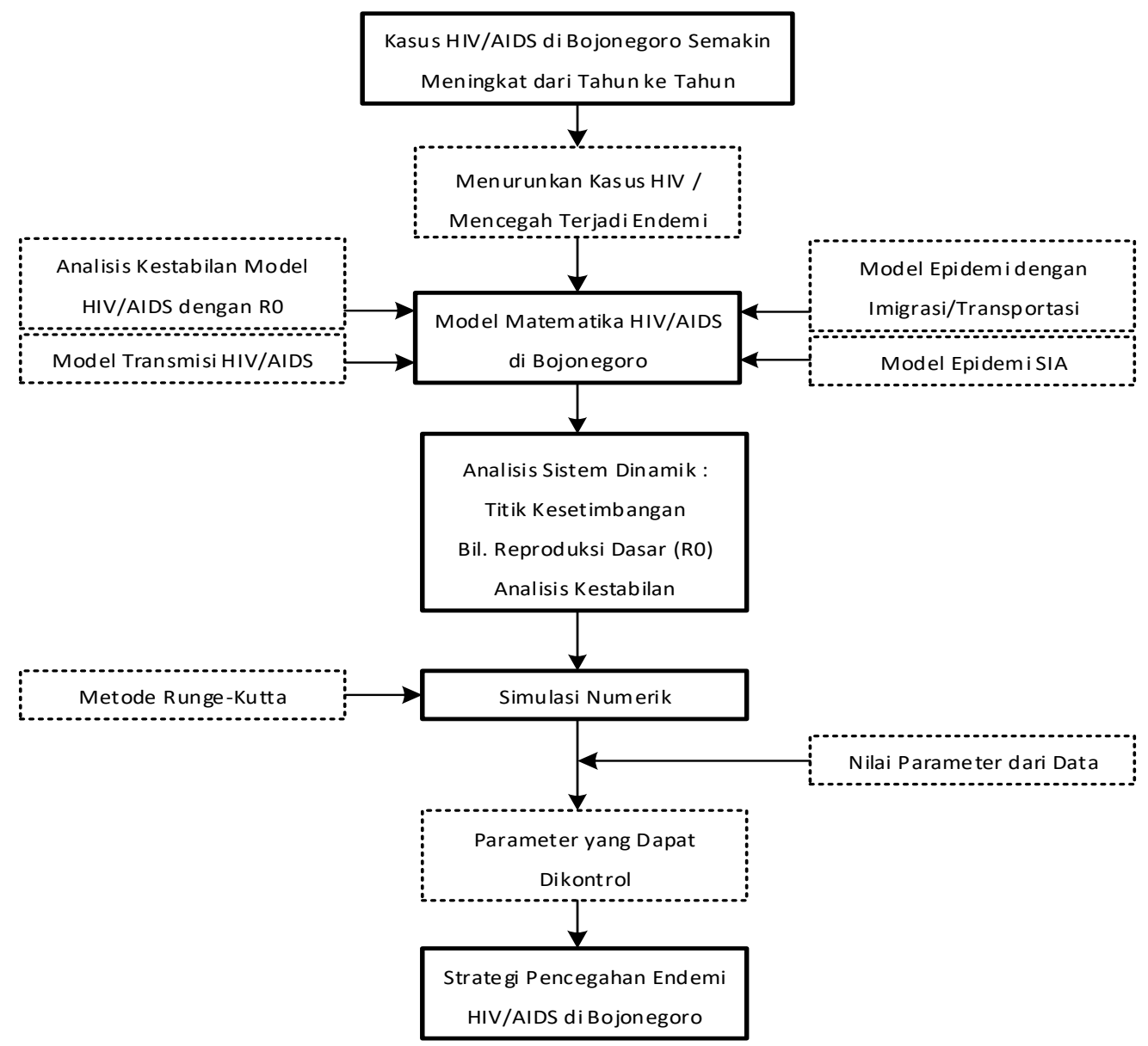

Gambar 1. Kerangka Konseptual Penelitian

\section{Hasil dan Pembahasan}

Model matematika penyebaran HIV dikonstruksi dengan pengembangan model dasar kompartemen SIA dengan mengkombinasi dari model Wan dan Cui (2007). Populasi terbagi menjadi dua kota, masing-masing kota terdiri dari kompartemen Susceptibles $(S)$, Infectives (I), dan AIDS (A). Susceptibles adalah populasi dari individu-individu rentan, Infective adalah populasi dari individu-individu terinfeksi HIV, AIDS adalah populasi individu yang telah mencapai fase AIDS (ODHA), Kota A adalah wilayah Kab.Bojonegoro, dan Kota B adalah wilayah lain yang identik. Sistem persamaan diferensial yang terbentuk adalah sebagai berikut.

$$
\begin{aligned}
& \frac{d S_{a}}{d t}=b-\alpha S_{a}+\alpha S_{b}-\beta S_{a} I_{a}-\gamma \alpha S_{b} I_{b}-d S_{a} \\
& \frac{d I_{a}}{d t}=\beta S_{a} I_{a}+\gamma \alpha S_{b} I_{b}-\alpha I_{a}+\alpha I_{b}-d I_{a}-\theta I_{a} \\
& \frac{d A_{a}}{d t}=\theta I_{a}-v A_{a}
\end{aligned}
$$




$$
\begin{aligned}
& \frac{d S_{b}}{d t}=b-\alpha S_{b}+\alpha S_{a}-\beta S_{b} I_{b}-\gamma \alpha S_{a} I_{a}-d S_{b} \\
& \frac{d I_{b}}{d t}=\beta S_{b} I_{b}+\gamma \alpha S_{a} I_{a}-\alpha I_{b}+\alpha I_{a}-d I_{b}-\theta I_{b} \\
& \frac{d A_{b}}{d t}=\theta I_{b}-v A_{b}
\end{aligned}
$$

dengan $S_{i}, I_{i}$, dan $A_{i}$ mewakili banyaknya populasi susceptible, infective, dan AIDS di kota $i$, $S_{i}, I_{i}, A_{i} \geq 0(i=1,2)$. Kedua kota diasumsikan identik, sehingga parameter yang digunakan di kedua kota sama. Parameter-parameter yang digunakan dinyatakan dalam Tabel 1.

Tabel 1. Nilai Parameter Berdasarkan Data

\begin{tabular}{lcc}
\hline \multicolumn{1}{c}{ Deskripsi } & Parameter & Nilai \\
\hline Laju kelahiran/hari & $b$ & 28.56 \\
\hline Rate kematian alami & $d$ & 0.00021 \\
\hline Rate penularan HIV & $\beta$ & 0.000113 \\
\hline Rate perpindahan penduduk & $\alpha$ & 0.002 \\
\hline Rate penularan antarwilayah & $\gamma$ & 0.000113 \\
\hline Rate perubahan dari HIV menjadi AIDS & $\theta$ & 0.435 \\
\hline Rate kematian akibat HIV/AIDS & $v$ & 0.253 \\
\hline
\end{tabular}

Berdasarkan perhitungan titik kesetimbangan diperoleh $\mathcal{R}_{0} \leq 1$, maka model mempunyai titik kesetimbangan tunggal yaitu titik titik kesetimbangan bebas penyakit

$$
P_{0}=\left(\frac{b}{d}, 0,0, \frac{b}{d}, 0,0\right)
$$

Jika $\mathcal{R}_{0}>1$, selain mempunyai titik kesetimbangan bebas penyakit, model juga memiliki titik kesetimbangan endemi

$$
P_{*}=\left(S_{a}, I_{a}, A_{a}, S_{b}, I_{b}, A_{b}\right),
$$

dengan

$$
\begin{gathered}
S_{a}=S_{b}=\frac{(d+\theta)}{(\beta+\gamma \alpha)} \\
I_{a}=I_{b}=\frac{b(\beta+\gamma \alpha)-d^{2}-\theta d}{(\beta+\gamma \alpha)(d+\theta)} \\
A_{a}=A_{b}=\frac{\theta b(\beta+\gamma \alpha)-\theta d^{2}-\theta^{2} d}{v(\beta+\gamma \alpha)(d+\theta)}
\end{gathered}
$$

Matriks Jacobi untuk titik kesetimbangan bebas penyakit adalah

$$
J\left(P_{0}\right)=\left(\begin{array}{ll}
A & B \\
B & A
\end{array}\right) \text {, dengan } A=\left(\begin{array}{ccc}
-d & -\frac{(\beta+\gamma \alpha) b}{d} & 0 \\
0 & \frac{(\beta+\gamma \alpha) b}{d}-(d+\theta) & 0 \\
0 & \theta & -v
\end{array}\right) \operatorname{dan} B=\left(\begin{array}{ccc}
0 & 0 & 0 \\
0 & 0 & 0 \\
0 & 0 & 0
\end{array}\right) .
$$

Berdasarkan sifat-sifat determinan diperoleh $\operatorname{det}\left(J\left(P_{0}\right)-\lambda I\right)=\operatorname{det}(A+B-\lambda I) \operatorname{det}(A-B-$ $\lambda I)$, sehingga nilai eigen matriks $J\left(P_{0}\right)$ dapat diketahui dengan menganalisis nilai eigen matriks $A+B$ dan $A-B$. Dari analisis nilai eigen matriks $A+B$ dan $A-B$ tersebut dapat diperoleh 


$$
\lambda_{1}=\lambda_{4}=-d, \lambda_{2}=\lambda_{5}=-v, \lambda_{3}=\lambda_{6}=\frac{(\beta+\gamma \alpha) b}{d}-(d+\theta)
$$

Misalkan nilai eigen $\lambda_{3}=\lambda_{6}$ adalah

$$
\frac{(\beta+\gamma \alpha) b}{d}-(d+\theta)<0
$$

maka

$$
\begin{gathered}
b(\beta+\gamma \alpha)-(d+\theta) d<0 \\
b(\beta+\gamma \alpha)<(d+\theta) d \\
\frac{b(\beta+\gamma \alpha)}{(d+\theta) d}<1
\end{gathered}
$$

Sehingga diperoleh bilangan reproduksi dasar

$$
\mathcal{R}_{0}=\frac{b(\beta+\gamma \alpha)}{(d+\theta) d}
$$

disimpulkan jika $\lambda_{3}=\lambda_{6}<0$ atau $\mathcal{R}_{0}<1$ maka :

1. Titik kesetimbangan bebas penyakit tersebut adalah stabil asimtotik.

2. Titik kesetimbangan endemik tidak ada karena nilai $I_{a}, A_{a}, I_{b}, A_{b}$ bernilai negatif.

Matriks Jacobi untuk titik kesetimbangan endemi adalah $J\left(P_{*}\right)=\left(\begin{array}{ll}A & B \\ B & A\end{array}\right)$, dengan

$$
A=\left(\begin{array}{ccc}
-\frac{b(\beta+\gamma \alpha)-d^{2}-\theta d}{(d+\theta)}-d & -(d+\theta) & 0 \\
\frac{b(\beta+\gamma \alpha)-d^{2}-\theta d}{(d+\theta)} & 0 & 0 \\
0 & \theta & -v
\end{array}\right), B=\left(\begin{array}{lll}
0 & 0 & 0 \\
0 & 0 & 0 \\
0 & 0 & 0
\end{array}\right)
$$

Sehingga dapat dibentuk

$$
A-B-\lambda I=A+B-\lambda I=\left(\begin{array}{ccc}
-\frac{b(\beta+\gamma \alpha)-d^{2}-\theta d}{(d+\theta)}-d-\lambda & -(d+\theta) & 0 \\
\frac{b(\beta+\gamma \alpha)-d^{2}-\theta d}{(d+\theta)} & -\lambda & 0 \\
0 & \theta & -v-\lambda
\end{array}\right)
$$

Untuk menentukan nilai eigen, dapat dengan memisalkan matriks $A-B-\lambda I \operatorname{dan} A+B-\lambda I$.

Misalkan

$A-B-\lambda I=\left[\begin{array}{ccc}A_{11}-\lambda & A_{12} & 0 \\ A_{21} & A_{22}-\lambda & 0 \\ 0 & \theta & -v-\lambda\end{array}\right]$

Dengan ekspansi kofaktor, maka didapat $(-v-\lambda)\left[\left(A_{11}-k\right)\left(A_{22}-k\right)-A_{21} A_{12}\right]=0$

Sehingga nilai eigen $\lambda_{1}=-v, \lambda_{2}$ dan $\lambda_{3}$ adalah akar dari $A_{11} A_{22}-\left(A_{22}+A_{11}\right) \lambda+$ $\lambda^{2}-A_{21} A_{12}=0$

$\lambda^{2}-\left(A_{22}+A_{11}\right) \lambda+A_{11} A_{22}-A_{21} A_{12}=0$

$$
\lambda_{2}+\lambda_{3}=\frac{-b}{a}=A_{22}+A_{11} \rightarrow A_{22}+A_{11}<0
$$




$$
\lambda_{2} \cdot \lambda_{3}=\frac{c}{a}=A_{11} A_{22}-A_{21} A_{12} \rightarrow A_{11} A_{22}-A_{21} A_{12}>0
$$

Dengan demikian jika $\lambda_{2}$. $\lambda_{3}$ bernilai positif, maka kemungkinan nilai $\lambda_{2}$ dan $\lambda_{3}$ adalah keduanya positif atau keduanya negatif. Sedangkan jika $\lambda_{2}+\lambda_{3}$ bernilai negatif, maka kemungkinan nilai $\lambda_{2}$ dan $\lambda_{3}$ adalah keduanya negatif. Sehingga nilai $\lambda_{2}$ dan $\lambda_{3}$ yang memenuhi kedua syarat tersebut adalah keduanya bernilai negatif. Demikian juga dengan cara yang sama, dari matriks $A-B-\lambda I$ diperoleh $\lambda_{4}, \lambda_{5}$ dan $\lambda_{6}$ yang semuanya negatif.

Kesimpulan jika $\mathcal{R}_{0}>1$ maka :

1. Titik kesetimbangan bebas penyakit tidak stabil.

2. Titik kesetimbangan endemik stabil asimtotik.

Dari data tersebut diperoleh $R_{0}=35.3823$, sehingga dengan menggunakan analisis sistem dinamik berada pada kondisi endemi dengan $P_{*}=\left(S_{a}^{*}, I_{a}^{*}, A_{a}^{*}, S_{b}^{*}, I_{b}^{*}, A_{b}^{*}\right)=$ $(3843.7,63.7688,109.642,3843.7,63.7688,109.642)$. Hasil simulasi numerik ditampilkan pada Gambar 5.3. Dari Gambar 2 diketahui bahwa dengan nilai awal yang diberikan yaitu $S_{0}=$ $10074, I_{0}=1, A_{0}=0.134$ untuk kedua kota, diperoleh sistem yang stabil di titik kesetimbangan endemi, hal tersebut berarti saat kondisi $\mathcal{R}_{0}>1$ maka dalam kurun waktu tertentu akan tetap terdapat populasi infective, dan AIDS. Gambar 3 merupakan dinamika populasi dari kondisi awal rata-rata populasi dalam 5 tahun terakhir menuju kondisi saat $t=2500$. Dalam gambar tersebut terlihat populasi susceptible stabil di titik 3843.7, populasi infective stabil di titik 63.77 , dan populasi AIDS stabil di titik 109.64. Kondisi ini kalau tidak dicegah akan berdampak serius bagi penyebaran virus HIV di Kab.Bojoegoro, sehingga perlu untuk menurunkan endemi yang ada di populasi I dan A.

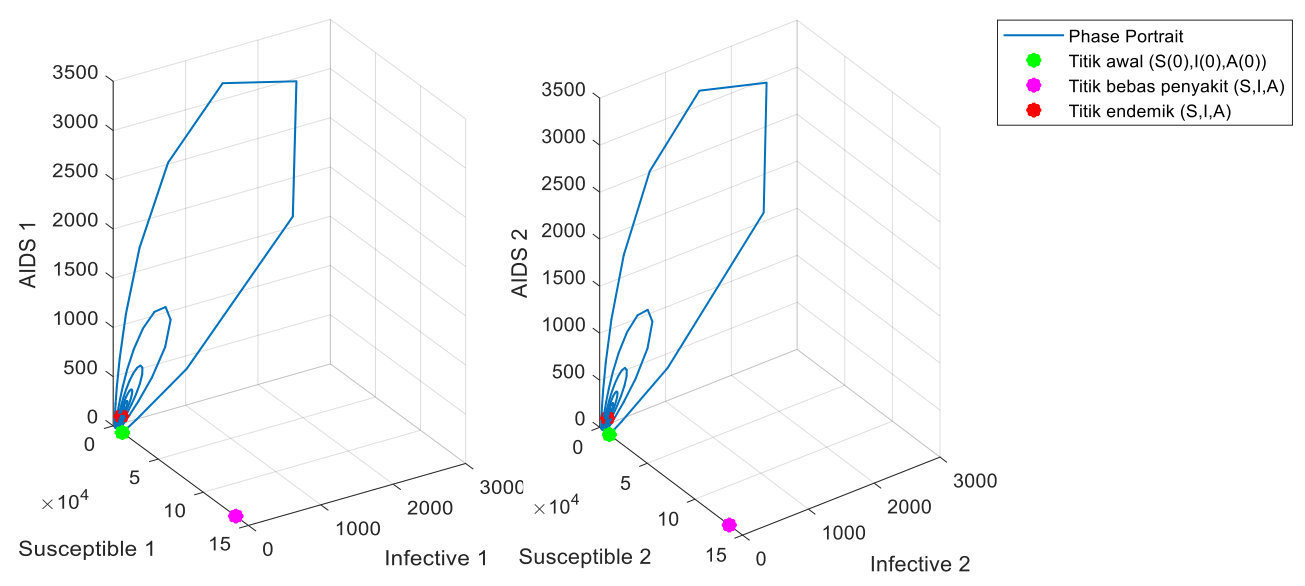

Gambar 2. Potret fase untuk $\mathcal{R}_{0}=35.3823$ 


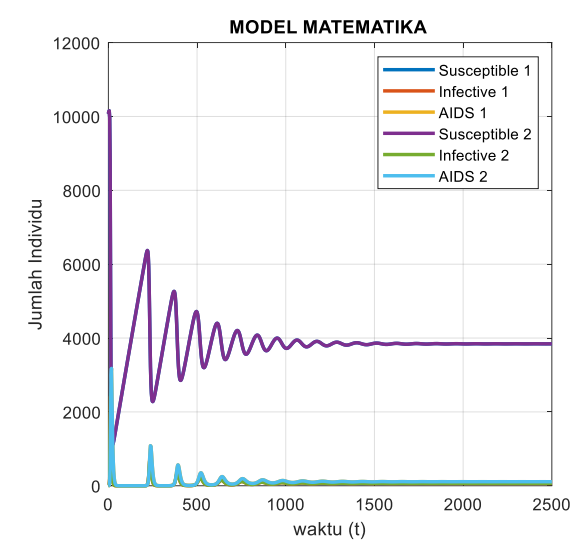

Gambar 3. Dinamika populasi saat $\mathcal{R}_{0}=35.3823$

Untuk membuat kondisi bebas penyakit, maka $\beta$ dan $\alpha$ diturunkan masing-masing menjadi $3 \times 10^{-6}$ dan $5 \times 10^{-4}$. Gambar 4 menggambarkan potret fase dan gambar 5 menggambarkan dinamika populasi saat nilai $\beta$ dan $\alpha$ diturunkan.
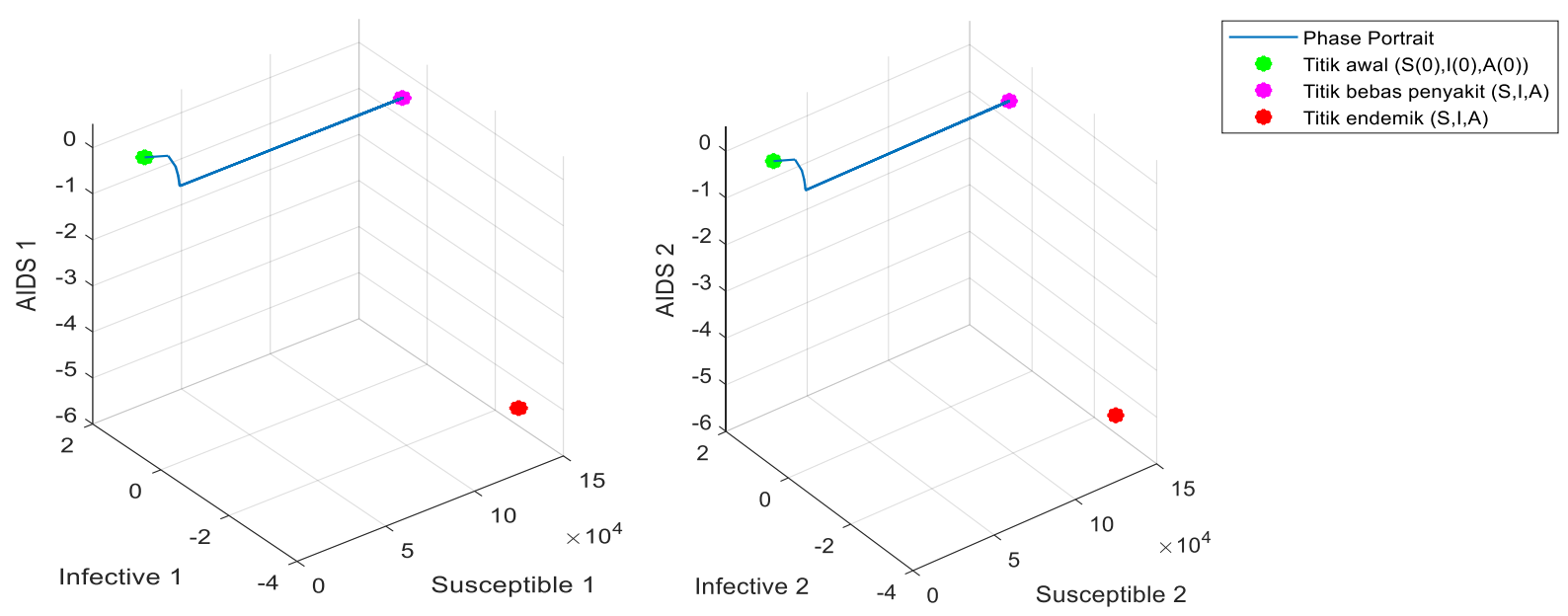

Gambar 4. Potret fase untuk $\mathcal{R}_{0}=0.9551$

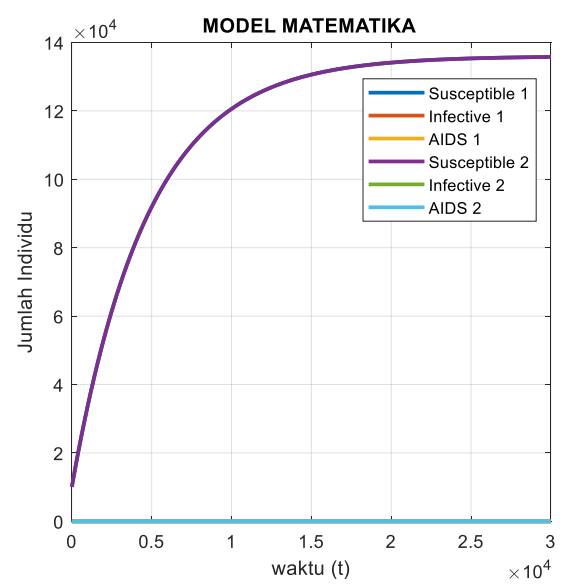

Gambar 5. Dinamika populasi saat $\mathcal{R}_{0}=0.9551$ 
Dari Gambar 4 diketahui populasi akan menuju titik kesetimbangan bebas penyakit dengan nilai $\mathcal{R}_{0}=0.9551$. Waktu yang diperlukan untuk memperoleh keadaan bebas penyakit yaitu saat $t=$ 30000 seperti pada gambar 5. Dalam gambar tersebut terlihat populasi susceptible stabil di titik 135900, populasi infective stabil di titik 0, dan populasi AIDS stabil di titik 0. Dari hasil simulasi tersebut, dengan menurunkan $\beta$ dan $\alpha$ diperoleh kondisi tanpa penyakit HIV/AIDS, yaitu keadaan dimana hanya terdapat populasi manusia yang sehat / susceptible.

\section{Simpulan dan Saran}

Perubahan kestabilan atau dinamika penyakit menular HIV/AIDS di kabupaten Bojonegoro dipengaruhi oleh perpindahan penduduk antar kota. Berdasarkan analisis yang telah dilakukan dalam penelitian ini diperoleh hasil kesimpulan yaitu

1. Diperoleh dua titik kesetimbangan, yaitu titik kesetimbangan bebas penyakit $P_{0}$ dan titik kesetimbangan endemik $P_{*}$.

2. Bilangan reproduksi dasar $\mathcal{R}_{0}$ menentukan eksistensi dan jenis kestabilan titik kesetimbangan. Jika $\mathcal{R}_{0}<1$ maka hanya terdapat satu titik kesetimbangan bebas penyakit yang stabil. Jika $\mathcal{R}_{0}>1$ maka terdapat dua titik kesetimbangan, titik kesetimbangan bebas penyakit yang tidak stabil, dan titik kesetimbangan endemik yang stabil.

3. Kondisi Kab.Bojonegoro saat ini berada pada kondisi endemi, sehingga strategi dalam pencegahan wabah HIV/AIDS yaitu dengan menurunkan bilangan reproduksi dasar sampai kurang dari satu. Untuk membuat kondisi $\mathcal{R}_{0}<1$ dilakukan dengan menurunkan rate penularan $\operatorname{HIV}(\beta)$ dan rate perpindahan penduduk $(\alpha)$, sehingga saat kondisi $\mathcal{R}_{0}<1$, Kab.Bojonegoro akan terbebas dari endemi HIV/AIDS.

Berdasarkan hasil pembahasan dalam penelitian ini, penulis dapat memberikan saran untuk penelitian-penelitian lanjutan yang bisa dikembangkan dari penelitian ini yaitu : model antar wilayah dapat dibuat tidak identik, sehingga model akan mendekati keadaan yang sebenarnya, pengambilan data juga sebaiknya dalam kurun waktu yang lebih lama sehingga data yang didapat dapat lebih valid.

\section{Referensi}

Anonimus, 2007. Apakah AIDS Itu?. (http://spiritia.or.id/li/bacali.php?lino=101, diakses 20 Januari 2017). Yayasan Spiritia.

Dinkes Kab.Bojonegoro. 2016. Profil Kesehatan Kabupaten Bojonegoro Tahun 2015. Bojonegoro.

Eduafo, S., I. K. Adu, F. T. Oduro, dan I. O. Darko. 2015. An SIA Model of HIV Transmission in Ghana. International Mathematical Forum. Volume 10(2) : 95-104. 
Infodatin. 2016. Situasi Penyakit HIV AIDS di Indonesia. Pusat Data dan Informasi Kementerian kesehatan RI : Jakarta Selatan.

Jiang, D., C. Ji, N. Shi, dan J. Yu. 2010. The Long Time Behavior of DI SIR Epidemic Model with Stochastic Perturbation. Journal of Mathematical Analysis and Applications. Volume $372: 162-180$.

Marsudi, M. dan R.B.E. Wibowo. 2013. Model Matematika Penyebaran HIV/AIDS dengan Edukasi Kesehatan. Natural B. Volume 2(1).

Wan, H. dan J. Cui. 2007. An SEIS Epidemic Model with Transport-Related Infection. Journal of Theoretical Biology. Volume 247(3) : 507-724. 